\title{
PREVALENCE AND MUTATIONS OF $\beta$-THALASSEMIA TRAIT AND ABNORMAL HEMOGLOBINS IN PREMARITAL SCREENING IN ÇANAKKALE PROVINCE, TURKEY
}

\author{
Uludağ A ${ }^{1}$, Uysal A ${ }^{2, *}$, Uludağ A ${ }^{3}$, Ertekin $\mathrm{YH}^{3}$, Tekin $\mathrm{M}^{3}$, Kütük B ${ }^{4}$, Silan F${ }^{1}$, Özdemir Ö${ }^{1}$
}

\begin{abstract}
*Corresponding Author: Associate Professor Ahmet Uysal, Department of Obstetrics and Gynecology, Çanakkale Onsekiz Mart University, Terzioglu Yerleskesi 17100, Çanakkale, Turkey. Tel: +90-533-2635540. Fax: +90-028-626-3597. E-mail: drahmetuysal@hotmail.com
\end{abstract}

\begin{abstract}
The prevalence of $\beta$-thalassemia ( $\beta$-thal) carriers in Turkey varies according to region but in general it is $2.0 \%$. Çanakkale is a city in the Aegean region of Turkey but no study about $\beta$-thal frequency in Çanakkale has been published to date. In this study, we aimed to investigate the frequency of $\beta$-thal mutations in this province. A total of 4452 couples ( 8904 individuals) applied for premarital thalassemia scans at the Çanakkale State Health Directorate Laboratory between January 2008 and June 2012 and scanning was done with high performance liquid chromatography (HPLC). Of $125 \beta$-thal carriers seen at the Medical Genetics Clinic, Çanakkale Onsekiz Mart University, Çanakkale, Turkey, for genetic counseling, 46 participated in the study. The remaining 79 patients could not be reached. The prevalence for $\beta$-thal carriers in Çanakkale was identified as $1.4 \%$ $(125 / 8904)$. One couple were both $\beta$-thal carriers. $\beta$-Globin gene analysis of 46 carriers found the total frequency of the three most common mutations was $45.6 \%$. These mutations were found to be $H B B$ :
\end{abstract}

\footnotetext{
${ }^{1}$ Department of Medical Genetics, Çanakkale Onsekiz Mart University, Çanakkale, Turkey

${ }^{2}$ Department of Obstetrics and Gynecology, Çanakkale Onsekiz Mart University, Çanakkale, Turkey

${ }^{3}$ Department of Family Medicine, Çanakkale Onsekiz Mart University, Çanakkale/Turkey

${ }^{4}$ Ministry of Health, Çanakkale Public Health Center, Çanakkale, Turkey
}

c. $93-21 \mathrm{G}>$ A [IVS-I-110 (G>A)], 26.08\% (12/46); $H B B$ : c. 17 18delCT [codon 5 (-CT)], $10.85 \%$ (5/46); $H B \bar{B}$ : c.20delA [codon $6(-\mathrm{A})]$ 8.69\% (4/46). This is the first report on the frequency and mutation profiles of $\beta$-thal for Çanakkale. The incidence of $\beta$-thal carriers in Çanakkale is below the average for Turkey. The most frequently observed mutation profile and rate of $\beta$-thal in our region is different from the other regions of Turkey.

Keywords: Abnormal hemoglobin $(\mathrm{Hb})$; $\beta$-Thalassemia ( $\beta$-thal); Premarital screening; Prevalence.

\section{INTRODUCTION}

$\beta$-Thalassemia ( $\beta$-thal) is an autosomal recessive hereditary anemia characterized by defective or insufficient globin chain synthesis in the hemoglobin $(\mathrm{Hb})$ molecule [1]. The rate of $\beta$-thal carriers in Turkey is generally $2.0 \%$. In some states in the Aegean region the rate is as high as $5.0 \%$. Some states in the Mediterranean region have rates of up to $10.0 \%$ [2-6].

Frequency of marriages among close relatives and a high birth rate, are the causes of the greater than expected births of children with $\beta$-thal in Turkey. The disease follows a wide spectrum of progression from slightly clinical $\beta$-thal minor to transfusion-depen$\operatorname{dent} \beta$-thal major ( $\beta$-TM). In the Turkish population, there are more than 30 different mutations described for $\beta$-thal; this broad molecular variety, the broad molecular definition of the disease, significantly hampers strategies and programs to prevent the disease [2,4-6]. 
There is no report in the scientific literature on the prevalence or mutation profile of $\beta$-thal for the city Çanakkale, which is in the Aegean region of Turkey. As a result, it was necessary to research the frequently observed $\beta$-thal mutations and determine the $\beta$-thal mutation profile of the region.

The primary aim of our study was to determine the frequency of $\beta$-thal in the premarital population and reveal the mutation types and allele frequencies. Thus, the most common genetic mutations in the Çanakkale region would be identified, and individuals who are patients and/or carriers would be provided with genetic counseling based on identified mutations. Additionally, the identified mutation may form the infrastructure for genetic scanning/ screening programs to be developed specifically for the region.

\section{MATERIALS AND METHODS}

This study received permission from the Çanakkale Onsekiz Mart University Medical Faculty Ethics Committee. A total of 4452 couples (8904 individuals) applied for premarital thalassemia scans at the Çanakkale State Health Directorate Laboratory between January 2008 and June 2012 and $\mathrm{Hb}$ fractionation was performed using ion exchange high performance liquid chromatography (HPLC) with the Tosoh G8 HPLC Analyzer (Tosoh Bioscience, Tokyo, Japan). Of $125 \beta$-thal carriers directed to the Department of Medical Genetics Clinic, Çanakkale Onsekiz Mart University, Çanakkale, Turkey, for genetic counseling, 46 participated in the study. The remaining 79 patients could not be reached. After being diagnosed, the patients were counseled about the mutations and prenatal diagnosis (PND) choices. After carriers signed a patient consent form, $2 \mathrm{~mL}$ peripheral blood was taken in a vacutainer containing EDTA as anticoagulant. DNA isolation of the samples was completed with the spin column method (QIAamp DNA Blood Mini Kit; Qiagen GmbH, Hilden, Germany).

The Sanger and pyrosequencing methods were performed for all three exons of the $\beta$-globin gene with the capillary electrophoresis ABI PRISM ${ }^{\circledR}$ 3130 Genetic Analyzer (Applied Biosystems, Foster City, CA, USA) and PyroMark Q24 Advanced (Qiagen) after polymerase chain reaction (PCR) amplification of all exons with specific primers with Ge-
neAmp ${ }^{\circledR}$ PCR system 9700 (Applied Bio-systems). The PCR was performed with a final volume of $40 \mu \mathrm{L}$ including $250 \mathrm{nM}$ primers, $0.2 \mathrm{mM}$ of each deoxynucleotides, $2 \mathrm{mM} \mathrm{MgCl}, 1 \mathrm{U}$ of Taq Polymerase (Taq DNA Polymerase, $5 \mathrm{U} / \mu \mathrm{L}$; Roche Life Science, Penzberg, Upper Bavaria, Germany) and $100 \mathrm{ng}$ of sample DNA. Sequence results were evaluated with SeqScape ${ }^{\circledR}$ software (Applied Biosystems), and the identified mutations were checked in both the National Center for Biotechnology Information (NCBI; Rockville Pike, Bethesda, MD, USA) blast and Ensembl databases. To statistically analyze the results, the Statistical Package for the Social Sciences (SPSS) version 16.0 (SPSS Inc., Chicago, IL, USA) was used.

\section{RESULTS}

In Çanakkale, premarital thalassemia scanning was completed for a total of 4452 couples ( 8904 individuals) between January 2008 and June 2012. The prevalence for $\beta$-thal carriers was identified as $1.4 \%(125 / 8904)$, while the prevalence for sickle cell anemia carriers was $0.06 \%(5 / 8904)$. One couple were both $\beta$-thal carriers. $\beta$-Globin gene analysis of 46 carriers found the total frequency of the three most common mutations was $45.65 \%$. These mutations were found to be $H B B$ : c. $93-21 \mathrm{G}>\mathrm{A}$ [IVS-I-110 $(\mathrm{G}>\mathrm{A})$ ], 26.08\% (12/46); HBB: c.17_18delCT [codon 5 (-CT)], 10.85\% (5/46); HBB: c.20delA [codon 6 $(-\mathrm{A})] \mathrm{8.69 \%}(4 / 46)$ (Table 1).

Unfortunately, the couple who were identified to both be $\beta$-thal carriers on premarital scanning did not have any genetic counseling. Their first child was born with $\beta$-TM and died at 2 years of age. They were referred to our clinic for genetic counseling in the 14th week of their second pregnancy. The couple were counseled and a series of genetic analyses were performed. There was no consanguinity but they were from the same village. Interestingly, the couple both had a deletion of the adenine nucleotide at codon 6 (Figure 1). Their $\beta$-globin gene series were exactly the same. To prevent the possibility of an improper operation, chimerism analysis was performed and the blood samples were proven not to be from a single person. In the 16th week of pregnancy, PND was performed with amniocentesis. After the procedure, the fetus was found to be homozygous for a normal $\beta$-globin gene. 
Table 1. Heterozygous $\beta$-globin gene mutations, numbers and frequencies (\%) in this study and comparison of frequencies with other studies performed in Turkey.

\begin{tabular}{|c|c|c|c|c|c|}
\hline \multirow{3}{*}{$\begin{array}{l}\text { Heterozygous Mutations } \\
\text { References } \\
H B B:\end{array}$} & & & \multicolumn{3}{|c|}{ Frequency } \\
\hline & \multicolumn{2}{|c|}{ This Study } & \multirow{2}{*}{$\begin{array}{c}\text { Antalya [7] } \\
\%\end{array}$} & \multirow{2}{*}{$\begin{array}{c}\text { Ankara [9] } \\
\%\end{array}$} & \multirow{2}{*}{$\begin{array}{c}\text { Istanbul [2] } \\
\%\end{array}$} \\
\hline & $n$ & $\%$ & & & \\
\hline c.93-21G $>$ A [IVS-I-110 $(\mathrm{G}>\mathrm{A})]$ & 12 & 26.08 & 42.30 & 49.01 & 39.20 \\
\hline c.17_18delCT [codon $5(-\mathrm{CT})]$ & 5 & 10.85 & 3.40 & 2.51 & 2.20 \\
\hline c. $20 \operatorname{del} \mathrm{A}[\operatorname{codon} 6(-\mathrm{A})]$ & 4 & 8.69 & - & 0.45 & $<1.00$ \\
\hline c. $92 \mathrm{G}>\mathrm{T}[\mathrm{IVS}-\mathrm{I}-1(\mathrm{G}>\mathrm{A})]$ & 3 & 6.52 & 5.10 & 7.99 & 5.50 \\
\hline c. $-137 \mathrm{C}>\mathrm{G}[-87(\mathrm{C}>\mathrm{G})]$ & 3 & 6.52 & - & 0.36 & $<1.00$ \\
\hline c. $25 \_26 \operatorname{del} A \mathrm{~A}$ [codon 8 (-AA)] & 3 & 6.52 & 3.20 & 7.63 & 6.10 \\
\hline c. $92+5 \mathrm{G}>\mathrm{C}[\mathrm{IVS}-\mathrm{I}-5(\mathrm{G}>\mathrm{C})]$ & 3 & 6.52 & 1.50 & 1.08 & 1.10 \\
\hline c. $20 \mathrm{~A}>\mathrm{T}[\operatorname{codon} 6(\mathrm{~A}>\mathrm{T})](\mathrm{Hb} \mathrm{S})$ & 2 & 4.34 & 6.50 & - & $<1.00$ \\
\hline c.316-106C > G [IVS-II-745 (C>G)] & 2 & 4.34 & 6.80 & 7.00 & 4.60 \\
\hline c. $135 \mathrm{delC}[\operatorname{codon} 44(-\mathrm{C})]$ & 2 & 4.34 & 3.20 & 3.23 & 1.30 \\
\hline c. $93-15 \mathrm{~T}>\mathrm{G}[\mathrm{IVS}-\mathrm{I}-116(\mathrm{~T}>\mathrm{G})]$ & 1 & 2.17 & 0.20 & 0.36 & $<1.00$ \\
\hline c. $315-1 \mathrm{G}>\mathrm{A}[\mathrm{IVS}-\mathrm{II}-1(\mathrm{G}>\mathrm{A})]$ & 1 & 2.17 & 8.80 & 5.92 & 5.4 \\
\hline c. $92+6 \mathrm{~T}>\mathrm{C}$ [IVS-I-6 $(\mathrm{T}>\mathrm{C})]$ & 1 & 2.17 & 7.00 & 4.67 & 9.5 \\
\hline c. $-78 \mathrm{~A}>\mathrm{C}[-28(\mathrm{~A}>\mathrm{C})]$ & 1 & 2.17 & - & - & - \\
\hline c. $-18 \mathrm{C}>\mathrm{G}\left[+33(\mathrm{C}>\mathrm{G})\left(5^{\prime} \mathrm{UTR}\right)\right]$ & 1 & 2.17 & - & - & - \\
\hline c. $118 \mathrm{C}>\mathrm{T}[\operatorname{codon} 39(\mathrm{C}>\mathrm{T})]$ & 1 & 2.17 & - & - & - \\
\hline c.2727_28insG [codons 8/9 $(+\mathrm{G})]$ & 1 & 2.17 & 1.50 & 1.44 & 1.50 \\
\hline & 46 & 100.00 & & & \\
\hline
\end{tabular}

5'UTR: 5' untranslated region.

\section{DISCUSSION}

$\beta$-Thalassemia is a well-known genetic disorder of the globin gene, with a worldwide distribution. The Ministry of Health and the Turkish National Hemoglobinopathies Council (MH and TNHC) reported a $4.3 \%$ prevalence of $\beta$-thal trait in a population of 377,399 healthy subjects from 16 cities in Turkey [6]. However, no study has reported the prevalence of $\beta$-thal trait and abnormal $\mathrm{Hbs}$ for the province of Çanakkale until now.

Çanakkale is located in the far west of Turkey between the Marmara and Aegean regions. Different to other areas of Turkey, the majority of the population is comprised of immigrants from Balkan countries and Romania. The sociocultural level of the city is above Turkey average.

Our study is the first to report these data, save for our preliminary premarital screening report of $1.45 \%$ limited to the city of Çanakkale alone. This rate was $0.06 \%$ for $\mathrm{Hb} \mathrm{S}(H B B: \mathrm{c} .20 \mathrm{~A}>\mathrm{T})$ carriers. This prevalence of $\beta$-thal carriers in the province is not high compared to the prevalence in Turkey as a whole. In İzmir (in the Aegean region of Turkey), the neighbor- ing provinces of Çanakkale, the prevalence of $\beta$-thal and $\mathrm{Hb} \mathrm{S}$ were 4.96 and $0.13 \%$, respectively [3].

In Turkey, 36 different $\beta$-thal mutations have been described to date. The most commonly identified mutations are, in order, $H B B$ : c. $93-21 \mathrm{G}>\mathrm{A}, H B B: \mathrm{c} .92+6 \mathrm{~T}>\mathrm{C}$ [IVS-I-6 $(\mathrm{T}>\mathrm{C})$ ] and $H B B$ : c.25_26delAA [codon 8 $(-\mathrm{AA})]$ [2]. In the Mediterranean region, 19 different mutations have been reported and the most frequently observed are $H B B$ : c.93-21G $>\mathrm{A}, H B B: \mathrm{c} .92+6 \mathrm{~T}>\mathrm{C}$ and $H B B:$ c. $-80 \mathrm{~T}>\mathrm{A}[-30(\mathrm{~T}>\mathrm{A})]$ mutations. The same study reported the $\mathrm{Hb} \mathrm{S}$ incidence as $10.3 \%$ [7].

This wide molecular variety, the molecular genetic description of the disease, significantly hampers strategies and programs to prevent the disease. In our region, according to the $\beta$-globin genetic analysis we conducted, there were 14 different mutations identified in carriers of $\beta$-thal. The most frequently observed mutation for $\beta$-thal in Turkey with a rate of about $40.0 \%$ is reported as $H B B$ : c. $93-21 \mathrm{G}>\mathrm{A}$ [2]. In our study, this mutation has the highest frequency of $26.08 \%$, lower than the average for Turkey and different to a range of regions in Turkey [2,7-9]. The frequency of $H B B:$ c. $93-21 \mathrm{G}>\mathrm{A}$ in $\beta$-thal mutations 


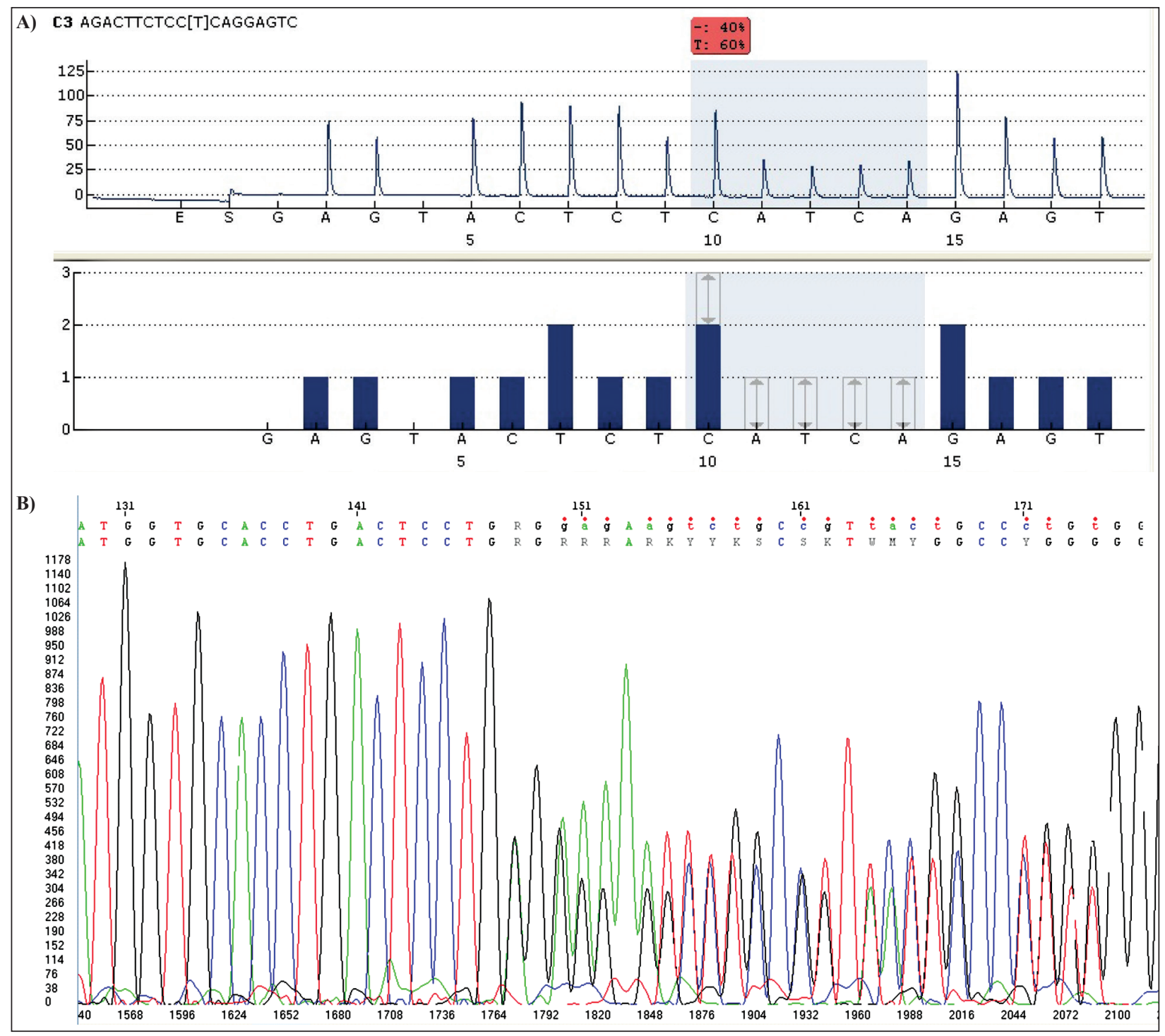

Figure 1. Detection of a frameshift mutation in the open reading frame, showing the codon 6 ( $-\mathrm{A})$ (HBB: c.20delA) deletion, analyzed by A) pyroseguencing and B) the Sanger sequencing technique.

exceeds $50.0 \%$ in Central Anatolia, but falls to $25.0 \%$ in East and Southeast Anatolia [2,10,11]. Keser et al. [8] calculated the frequency of $H B B$ : c.93-21G $>$ A as $35.6 \%$ in the Antalya region in their 2004 study. The same mutation was reported as $49.02 \%$ in the Central Anatolia region by Beksaç et al. [9,11].

Interestingly, although there are so many immigrants in Çanakkale from the Balkans, who came during the Balkan War (1912), the mutation profile is different from Balkan countries, especially Romania [12]. Selected marriages because of cultural differences in those days may cause this difference.

As seen in our study, $\beta$-thal is an important health problem in Turkey. As there is no certain treatment of $\beta$-thal, it is very important to determine the mutations and the carriers for preventing the disease. For correct genetic counseling it is necessary to know the exact mutations within the families. The couple both found to be $\beta$-thal carriers in our study did not have genetic counseling so they had lost their first child because of $\beta$-TM. Prenatal diagnosis by amniocentesis of the fetus for their second pregnancy was found to be homozygous for a normal $\beta$-globin gene. This dramatic family history emphasizes the importance of prenatal screening, especially for carriers. The wide heterogeneity of $\beta$-thal at a molecular level is an important barrier to diagnosis and prevention of the disease. 
This is the first report on the frequency and mutation profiles of $\beta$-thal for Çanakkale. The incidence of $\beta$-thal carriers in Çanakkale is below the average of Turkey. A high level of sociocultural population and low rates of consanguineous marriages could cause this. The most frequently observed mutation profile and rate of $\beta$-thal in our region is different to the mutation profiles and rates observed in different regions of Turkey. To prevent an increase in $\beta$-thal incidence and ensure families become parents of healthy children, it is necessary to increase consanguinity marriage education, genetic counseling before pregnancy and prenatal genetic screening programs.

Declaration of Interest. The authors report no conflicts of interest. The authors alone are responsible for the content and writing of this article.

\section{REFERENCES}

1. Tuzmen S, Schechter AN. Genetic diseases of hemoglobin: Diagnostic methods for elucidating $\beta$-thalassemia mutations. Blood Rev. 2001; 15(1): 19-29.

2. Başak AN. The molecular pathology of $\beta$-thalassemia in Turkey: The Boğaziçi University experience. Hemoglobin. 2007; 31(2): 233-241.

3. Uysal A, Genc A, Taşyürek N, Türkyilmaz B. Prevalence of $\beta$-thalassemia trait and abnormal hemoglobin in premarital screening in the Province of Izmir, Turkey. Pediatr Hematol Oncol. 2013; 30(1): 46-50.

4. Tadmouri GO, Tüzmen S, Ozçelik H, Ozer A, Baig SM, Senga EB, et al. Molecular and population genetic analyses of $\beta$-thalassemia in Turkey. Am J Hematol. 1998; 57(3): 215-220.
5. Ozkinay F, Onay H, Karaca E, Arslan E, Erturk B, Ece Solmaz A, et al. Molecular basis of $\beta$-thalassemia in the population of the Aegean region of Turkey: Identification of a novel deletion mutation. Hemoglobin. 2015; 15(1): 1-5.

6. Canatan D, Kose MR, Ustundag M, Haznedaroglu D, Ozbas S. Hemoglobinopathy control program in Turkey. Community Genet. 2006; 9(2): 124-126.

7. Mendilcioglu I, Yakut S, Keser I, Simsek M, Yesi-lipek A, Bagci G, et al. Prenatal diagnosis of $\beta$-thalassemia and other hemoglobinopathies in southwestern Turkey. Hemoglobin. 2011; 35(1): 47-55.

8. Keser I, Sanlioglu AD, Manguoglu E, Guzeloglu Kayisli O, Nal N, Sergin F, et al. Molecular analysis of $\beta$-thalassemia and sickle cell anemia in Turkey. Acta Haematol. 2004; 111(4): 205-210.

9. Beksaç MS, Gumruk F, Gurgey A, Cakar N, Mumusoglu S, Ozyuncu O, et al. Prenatal diagnosis of hemo-globinopathies in Hacettepe University, Turkey. Pediatr Hematol Oncol. 2011; 28(1): 51-55.

10. Başak AN, Ozçelik H, Ozer A, Tolun A, Aksoy M, Ağaoğlu L, et al. The molecular basis of $\beta$-thalassemia in Turkey. Hum Genet. 1992; 89(3): 315-318.

11. Genc A, Tastemir Korkmaz D, Buyukleyla M, Celiker M. Prevalence and molecular analysis of $\beta$-thalassemia in Adiyaman, Turkey. Hemoglobin. 2012; 36(2): 131-138.

12. Cherry L, Calo C, Talmaci R, Perrin P, Gavrilla L. $\beta$-Thalassemia haplotypes in Romania in the context of genetic mixing in the Mediterranean area. Hemoglobin. 2016; 40(2): 85-96. 
